\title{
Implementasi Model Delone and McLean Pada Analisis Google Classroom Sebagai Media Pembelajaran Daring Saat Pandemi Covid-19
}

\author{
Dede Wintana ${ }^{1}$, Denny Pribadi², Yusti Farlina ${ }^{3}$, Taufik Hidayatulloh4 \\ 1,2,3,4 Universitas Bina Sarana Informatika \\ e-mail: ${ }^{1} \underline{\text { dede.dwe@bsi.ac.id, }{ }^{2} \text { denny.dpi@bsi.ac.id, }{ }^{3} \text { Yusti.yfa@bsi.ac.id, }{ }^{4} \underline{T} \text { aufik.tho@bsi.ac.id }}$
}

\begin{abstract}
Abstraksi
Pandemi Covid-19 yang masih melanda seluruh dunia sampai hari ini, mengubah berbagai kebiasaan dan kegiatan masyarakat karena anjuran dari pemerintah untuk beraktivitas di rumah, imbas pembatasan sosial ini berlaku pada semua sektor tak terkecuali dunia Pendidikan dalam kegiatan belajar mengajar, sekolah-sekolah diharuskan untuk menggelar Kegiatan belajar mengajar secara daring agar kegiatan belajar-mengajar tetap berjalan meskipun dari rumah, salah satu media belajar daring yang di manfaatkan yakni Google Classroom, selain mudah digunakan google classroom juga gratis bisa digunakan oleh siapa saja. MA Muhammadiyah Kadudampit merupakan salah satu sekolah yang menggunakan google classroom dalam kegiatan belajar mengajar selama pandemi covid-19. Penelitian ini bertujuan untuk analisis faktor-faktor dalam mengukur keberhasilan penggunaan google classroom dalam kegiatan belajar mengajar di masa pandemi covid-19 pada siswa-siswi MA Muhammadiyah Kadudampit mengenai efektifitas penggunaan google classroom selama kegiatan belajar dari rumah, dengan menggunkan model kesuksesan sistem informasi Delone and McLean. Data diperoleh dari 39 siswa yang di wawancara secara langsung yang di kumpulkan melalui media kuesioner, dan di oleh menggunakan aplikasi Partial Least Square (PLS). Hasil pengujian menunjukan variable kualitas sistem dan kulitas Pelayanan tidak berpengaruh signifikan terhadap variable kualitas pengguna, sedangkan varibel lain menunjukan pengaruh yang signifikan, penggunaan google classroom pada kegiatan belajar daring diperoleh nilai goodness Of Fit (GoF) 0,71 atau 71\%, maka model pengujian kesuksesan model pembelajan daring dengan menggunakan Model Delone and Mclean dinyatakan cukup sesuai secara substansional dalam pengujian penelitian.
\end{abstract}

Kata Kunci: Classroom,Delon and McLean,Covid-19

\begin{abstract}
The Covid-19 pandemic, which is still engulfing the whole world to this day, has changed various habits and activities of the community due to the government's recommendation to do activities at home, the impact of this social restriction applies to all sectors including the world of education in teaching and learning activities, schools are required to holding online teaching and learning activities so that teaching and learning activities can continue even from home, one of the online learning media that is used Google Classroom, besides being easy to use, Google Classroom is also free for anyone to use. MA Muhammadiyah Kadudampit is one of the schools that uses google classroom in teaching and learning activities during the covid-19 pandemic. This study aims to analyze the factors in measuring the success of using google classroom in teaching and learning activities during the covid-19 pandemic for MA Muhammadiyah Kadudampit students regarding the effectiveness of using google classroom during learning activities from home, using the success model of the Delone and Mclean information system. Data were obtained from 39 students who were interviewed directly and collected through questionnaires, and using the Partial Least Square (PLS) application. The test results show that the system quality variable and service quality have no significant effect on the
\end{abstract}


user quality variable, while other variables show a significant influence, the use of google classroom on online learning activities obtained a goodness of fit (GoF) value of 0.71 or $71 \%$, then the test model The success of the online learning model using the Delone and Mclean Model is stated to be quite substantially appropriate in research testing.

\section{Keywords:}

Classroom,Delon

\section{Pendahuluan}

Pandemi virus Corona (COVID 19) yang sedang melanda didunia merupakan masalah global yang terjadi didunia yang mengakibatkan perubahan besar dalam berbagai aspek kehidupan, salah satunya di Indonesia yang mengakibatkan situasi berubah secara drastis, pada saat sebelum pandemi masyarakat bisa hidup normal dan saling berinteraksi secara langsung akan tetapi saat ini semua berubah dan beradaptasi menjadi serba online atau daring tak terkecuali dibidang pendidikan.(Suriadi et al., 2021)

Kegiatan belajar online atau daring dilakukan sebagai salah satu upaya dilakukan pemerintah dalam memutus penyebaran virus, dengan dikeluarkannya PP Nomor 21 tahun 2020 tentang Pembatasan Sosial Berskala Besar Dalam Rangka Percepatan Penanganan Covid-19 yang berakibat pada pembatasan berbagai aktivitas termasuk kegiatan belajar mengajar sekolah. Kegiatan Belajar Dari Rumah (BDR) resmi di keluarkan melalui Surat Edaran dari kementrian pendidikan dan kebudayaan Nomor 36962/MPK.A/HK/2020 tentang pembelajaran secara online/daring dan bekerja dari rumah dalam upaya pencegahan penyebaran Corona Virus Disease (COVID19).(Kurniati et al., 2020)

Berbagai Aplikasi pembelajaran online dimanfaatkan untuk mendukung proses kegiatan belajar mengajar agara tetap berjalan di masa pandemi(Harefa \& Sumiyati, 2020). Pengimplementasian media pembelajaran online seperti multimedia, yang banyak diterapkan pada proses pembelajaran pada masa pandemic saat ini yakni google classroom.

Google classroom merupakan salah satu learning management system (LMS) yang bertujuan untuk membantu dalam mengatasi kesulitan belajar secara tatap muka tatap muka seperti saat ini(Maulana, 2021) kelebihan dari google classroom : pertama, google classroom merupakan sistem pembelajaran tanpa kertas, gratis dan dapat penunjang produktivitas pembelajaran, Kedua, pembelajaran

\section{and}

McLean,Covid-19

menggunakan google classroom tidak harus berada di ruangan yang sama. Ketiga, google classroom praktis bagi pendidik dan peserta didik.(Wiguna et al., 2020)

Namun pada aplikasi google classroom ini terdapat kelemahan, kelemahan dari googleclassroom terletak pada fitur untuk diskusinya seperti videocall sehingga tidak banyak menggunakan kuota, sehingga hanya bisa menyampaikan pesan melalui teks. Hal ini mengakibatkan interaksi atau komunikasi antara guru dan mjurid kurang, dan siswa kurang memahami pelajaran yang disampaikan karena hanya berupa teks dan video saja, tidak seperti google meet atau Zoom meeting(Wulandari, 2021) dan kelemahan lainnya seperti seperti tampilan yang kurang menarik, dan pengiriman file yang harus dipantau serta pengaturan waktu yang masih dapat diubah(Suri, 2020)

Berdasarkan uraian di atas, maka pada peneliti melakukan analisis mengenai penggunaan google classroom bagi siswa pada masa pandemi covid-19, dengan menggunakan model analisis Delone and McLean.

DeLone dan McLean Information Success Model atau Model Kesuksesan Sistem Informasi DeLone dan McLean(Yuliana \& Afriani, 2020), Delone Merupakan suatu model penelitian yang dikembangkan dalam mengukur kesuksesan suatu sistem informasi berdasarkan penelitian yang dilakukan oleh DeLone dan McLean (1992). Pada model DeLone dan McLean atau yang lebih dikenal dengan D\&M IS Success ini dimensi-dimensi kesuksesannya yang diukur semuanya saling berkaitan (Hidayatullah et al., 2020)

\section{Metode Penelitian}

Pada penelitian ini dilakukan pengumpulan data menggunakan kuesioner pada siswa/siswa yang ada di sekolah MA Muhammadiyah Kadudampit dengan model random sampling, dengan tujuan untuk menganalisis terhadap penggunaan Google Classroom sebagai media pembelajaran di 
masa pandemic covid-19, dari hasil yang diperoleh penulis akan menggunkan model Delone and McLean metode analisis SEM (Structural Equation Modeling ).

\subsection{Google Classroom}

Google classroom adalah suatu aplikasi pembelajaran campuran yang diperuntukkan untuk ruang lingkup pendidikan yang bertujuan untuk menemukanjalan keluar atas kesulitan dalam membuat, membagikan dan menggolonggolongkan setiap kegiatan belajar mengajar secara daring(Asnawi, 2018) google classroom dapat membantu dalam kegiatan belajar mengajar dalam memantau dalam pemecahan masalah pembelajaran secara daring dengan efektif dan efisien(Nurfalah, 2019)

2.2 Metode SEM

Metode SEM merupakan perkembangan dari analisis jalur (path analysis) dan regresi berganda (multiple regression) yang sama-sama merupakan bentuk model analisis multivariat (multivariate analysis)(Vogt, 2015). Pada Pemodelan SEM melibatkan variabel laten yang mempunyai hubungan linier dan semua nilai observasinya berdistribusi multivariat normal. SEM dapat menghasilkan persamaan yang valid apabila terpenuhi asumsi asumsi yang dibutuhkan yaitu normal multivariat dan linieritas. SEM merupakan metode gabungan dari analisis regresi, analisis jalur, dan analisis faktor(Nariswari \& Iriawan, 2012)

SEM merupakan bagian dari teknik statistik yang digunakan untuk membangun dan menguji model statistik yang biasanya dalam bentuk model-model sebab akibat. SEM pada dasarnya merupakan teknik hibrida yang meliputi aspek-aspek penegasan (confirmatory) dari analisis faktor, analisis jalur dan regresi yang dapat dianggap sebagai kasus khusus dalam SEM(Farabi, 2016)

\subsection{PLS}

PLS (Partial Leaste Square) merupakan metode alternatif dari Structural Equation Modeling (SEM) yang bisa digunakan untuk mengatasi permasalahan hubungan diantara variabel yang kompleks namun dengan jumlah sampel datanya kecil (30 sampai 100).(Astalini et al., 2018) PLS merupakan metode analisis yang powerful karena tidak mengasumsikan data harus dengan pengukuran tertentu, dapat diterapkan pada semua skala data, tidak membutuhkan banyak asumsi dan ukuran sample(Kualitas et al., 2012) PLS SEM Memiliki tingkat fleksibilitas yang tinggi untuk penelitian regresi yang menghubungkan antara teori dan data, juga mampu melakukan analisis jalur path dengan tetap menggunkan variable laten(Rifai, 2015)

2.4 Delone McLean

Delone and McLean Merupakan model penelitian yang dikembangkan untuk mengukur kesuksesan suatu sistem informasi berdasarkan penelitian yang dilakukan oleh DeLone dan McLean (Hidayatullah et al., 2020) Model pengukuran keberhasilan sistem informasi Delon dan Mclean merefleksikan ketergantungan dari enam Pengukuran sistem informasi. Keenam elemen atau faktor pengukuran dari model ini adalah (1) Kualitas Sistem, (2) Kualitas Informasi, (3) Kualitas Pelayanan, (4) Penggunaan, (5)Kepuasan Pengguna, dan (6) Manfaat Bersih.(Prayudi \& Oktapiani, 2020)

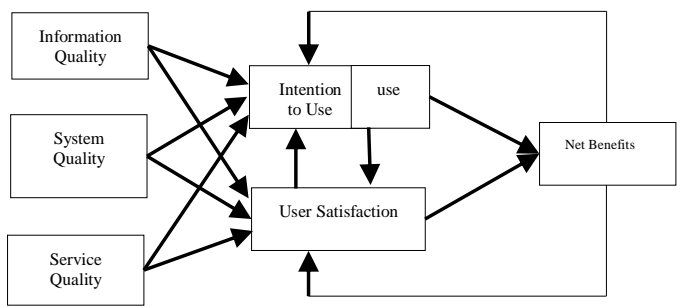

Gambar 1 Model Delone and McLean (2003)

Dari model Gambar 1 dibuat model hipotesis penelitian dengan menggunakan model penelitian sesuai dengan kebutuhan, variable yang di gunkan pada penelitian ini: Kemudahan pengguna, Kualitas Sistem, Kualitas Pelayanan, Kualitas Informasi, kulitas kepuasan dan manfaat. Pada penelitian ini ada 3 Variabel yang digunkan sebagai variable independent yaitu, Kualitas informasi (KI), Kualitas system (KS), Kualitas pelayanan (KP) sedangkan untuk variabel dependent, atau variabel yang hasilnya di pengaruhi oleh variabel lain yakni Pengguna(P), Kepuasan pengguna (KPG) dan Manfaat bersih (MB). 


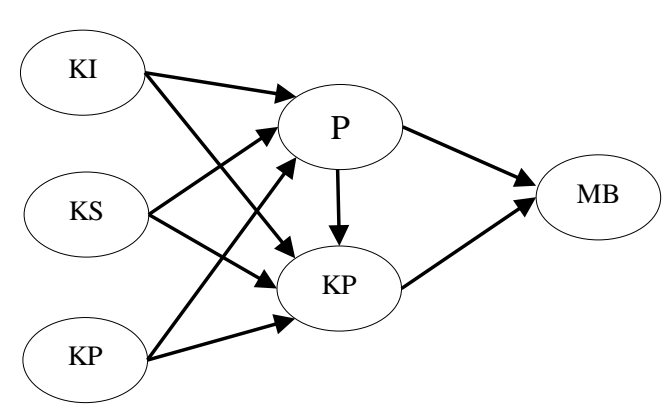

Gambar 2 Model Penelitian

Dari Model diatas dibentuk sebuah hipotesis Berdasarkan pada konsep pengaruh antar variabel, maka disusunlah hipotesis sebagai berkut:

$\mathrm{H} 1$ : Apakah kualitas informasi berpengaruh signifikan terhadap penggunaan?

H2: Apakah kualitas informasi berpengaruh signifikan terhadap kepuasan pengguna?

H3: Apakah kualitas sistem berpengaruh signifikan terhadap penggunaan?

H4: Apakah kualitas sistem berpengaruh signifikan terhadap kepuasan pengguna?

H5: Apakah kualitas pelayanan berpengaruh signifikan terhadap penggunaan?

H6: Apakah kualitas pelayanan berpengaruh signifikan terhadap kepuasan pengguna?

H7: Apakah pengguna berpengaruh signifikan terhadap kepuasan pengguna?

H8: Apakah pengguna berpengaruh signifikan terhadap manfaat bersih?

H9: Apakah kepuasan pengguna berpengaruh signifikan terhadap manfaat bersih?

Table 1 Variabel dan Indikator

\begin{tabular}{|c|c|c|}
\hline VARIABEL & INDIKATOR & $\begin{array}{l}\text { Jumlah } \\
\text { item }\end{array}$ \\
\hline \multirow{5}{*}{$\begin{array}{l}\text { Kualita } \\
\text { informasi }\end{array}$} & $\mathrm{X} 1=$ ketepatan waktu & 1 \\
\hline & $\mathrm{X} 2=$ keringkasan & 1 \\
\hline & $\mathrm{X} 3=$ mudah difahami & 1 \\
\hline & X4= aktualitas & 1 \\
\hline & $\mathrm{X} 5=$ relevansi & 1 \\
\hline \multirow{4}{*}{ Kualitas sistem } & $\mathrm{X} 6=$ ketersediaan sistem & 1 \\
\hline & $\mathrm{X} 7=$ kecepatan respon & 1 \\
\hline & $\mathrm{X} 8=$ flexsibelitas & 1 \\
\hline & $\mathrm{X} 9=$ kemudahan pengguna & 1 \\
\hline
\end{tabular}

\begin{tabular}{|c|c|c|}
\hline & $\begin{array}{l}\mathrm{X} 10=\text { kelengkapan } \\
\text { berintegrasi }\end{array}$ & 1 \\
\hline & $\mathrm{X} 11=$ kendala sistem & 1 \\
\hline & $\mathrm{X} 12=$ konsistensi sistem & 1 \\
\hline \multirow{3}{*}{$\begin{array}{l}\text { Kualitas } \\
\text { pelayanan }\end{array}$} & $\mathrm{X} 13=$ daya tanggap & 1 \\
\hline & $\mathrm{X} 14=$ jaminan & 1 \\
\hline & $\mathrm{X} 15=$ empati & 1 \\
\hline \multirow{4}{*}{ Pengguna } & Y1=waktu menggunakan & 1 \\
\hline & Y2=frekwensi penggunaan & 1 \\
\hline & Y3=lama waktu koneksi & 1 \\
\hline & $\begin{array}{l}\text { Y4= pengulangan } \\
\text { penggunaan }\end{array}$ & 1 \\
\hline \multirow{4}{*}{$\begin{array}{l}\text { Kepuasan } \\
\text { pengguna }\end{array}$} & Y5=penilaian kepuasan & 1 \\
\hline & $\begin{array}{l}\text { Y6 = kesulitan penggunaan } \\
\text { sistem }\end{array}$ & 1 \\
\hline & $\begin{array}{l}\text { Y7=kenyamanan } \\
\text { penggunaan sistem }\end{array}$ & 1 \\
\hline & $\begin{array}{l}\text { Y8= persyaratan kepuasan } \\
\text { penggunaan sistem }\end{array}$ & 1 \\
\hline \multirow{7}{*}{ Manfaat bersih } & $\begin{array}{l}\text { Y9= kesenangan terhadap } \\
\text { penggunaan sistem }\end{array}$ & 1 \\
\hline & $\begin{array}{l}Y 10=\text { menumbuhkan } \\
\text { kreatifitas }\end{array}$ & 1 \\
\hline & $\begin{array}{l}\text { Y11= peningkatan } \\
\text { pengetahuan }\end{array}$ & 1 \\
\hline & $\mathrm{Y} 12=$ manfaat & 1 \\
\hline & $\begin{array}{l}\text { Y13= kemampuan } \\
\text { memecahkan masalah }\end{array}$ & 1 \\
\hline & $\begin{array}{l}\text { Y14= meningkakan } \\
\text { partisipasi }\end{array}$ & 1 \\
\hline & $\begin{array}{l}\text { Y15 = tercapainya sharing } \\
\text { pengetahuan }\end{array}$ & 1 \\
\hline
\end{tabular}

\section{Hasil dan Pembahasan}

Analisis impelementasi penggunaan google classroom dalam mendukung pembelajaran daring masa pandemi covid-19 dengan menggunakan model Delone and McLean dapat terlihat pada gambar 3 berikut:



Gambar 3 Model Delone Mclean 
Pengujian model dilakukan dengan menggunakan aplikasi PLS (Partial Least Square 2) dan diperoleh hasil pada gambar 3 . Diperoleh bahwa nilai pada $\times 10 . X 11, X 15$, $\mathrm{Y} 1, \mathrm{Y} 3, \mathrm{Y} 6$ dan $\mathrm{Y} 15$ memiliki nilai di bawah 0,5 , sedangkan syarat validitas PLS dimana nilai minimum diharuskan mencapai 0,5(Agustina \& Kriwangko, 2017), maka variable $\mathrm{X} 10, \mathrm{X} 11, \mathrm{X} 15, \mathrm{Y} 1, \mathrm{Y} 3, \mathrm{Y} 6$, dan $\mathrm{Y} 15 \mathrm{di}$ hapus.

Selanjutnya dilakukan pengujian outer model dengan melakukan evaluasi validitas Convergen, Validitas Diskriminan dan Uji reliabilitas pada model.

3.1 Uji Validitas Convergen Berdasarkan pada pengujian validitas convergen diperoleh hasil penelitian sebagai berikut:

Table 2 Hasil pengujian Validitas Convergen

\begin{tabular}{lc}
\hline Y10 & 0,645116 \\
\hline Y11 & 0,933977 \\
\hline$Y 12$ & 0,645116 \\
\hline$Y 13$ & 0,933977 \\
\hline$Y 14$ & 0,913408 \\
\hline$Y 15$ & $\mathbf{0 , 3 2 0 1 1 9}$ \\
\hline
\end{tabular}

3.2 Pengujian Validitas Discriminan

1. Pengujian $\operatorname{AVE}(($ average variance extracted)

Hasil pengujian (average variance extracted) diperoleh hasil pengujian sebagai berikut:

Table 3 Nilai AVE

\begin{tabular}{cccl}
\hline & AVE & \multicolumn{1}{c}{ Ket } \\
\hline & KI & 0,691566 & Valid \\
\hline & KS & 0,454971 & tidak valid \\
\hline & KP & 0,458765 & tidak valid \\
\hline & $\mathbf{P}$ & 0,532938 & Valid \\
\hline & KPG & 0,72896 & Valid \\
\hline & MB & 0,585627 & Valid
\end{tabular}

Berdasarkan table 3 menunjukan bahwa Nilai KS dan KP dibawah 0,5 sedangkan nilai (Average Variance Extracted) yang diterima adalah $\geq 0,50$ (Agustina \& Kriwangko, 2017) maka pada variable $\mathrm{KS}$ dan $\mathrm{KP}$ tidak memenuhi dalam uji secara Convergen Validity dan harus di buang.

Selanjutnya dilakukan pengujian Cross Validation

2. Cross Validation

Table 4 Cross Validation

\begin{tabular}{|c|c|c|c|c|c|c|c|c|c|c|}
\hline \multirow{2}{*}{$\begin{array}{r}\text { X14 } \\
\text { X15 }\end{array}$} & 0,831077 & & & & \multicolumn{4}{|c|}{ Table 4 Cross Validation } & \multirow[b]{2}{*}{ KPG } & \multirow[b]{2}{*}{ MB } \\
\hline & $-0,178663$ & & & & KI & KS & KP & $\mathbf{P}$ & & \\
\hline Y1 & & 0,406967 & & $\mathrm{X} 1$ & 0,798596 & 0,664863 & 0,652026 & 0,553317 & 0,650304 & 0,661293 \\
\hline Y2 & & 0,942476 & & $\mathrm{X} 2$ & 0,904149 & 0,853938 & 0,831077 & 0,494428 & 0,970033 & 0,933977 \\
\hline Y3 & & $-0,435442$ & & $\mathrm{X3}$ & 0,93996 & 0,853892 & 0,784883 & 0,485579 & 0,964256 & 0,913408 \\
\hline Y4 & & 0,942476 & & $\mathrm{X4}$ & 0,785107 & 0,703365 & 0,533467 & 0,378145 & 0,778938 & 0,636301 \\
\hline Y5 & & & 0,970033 & $\times 5$ & 0,708991 & 0,686938 & 0,704628 & 0,690894 & 0,567458 & 0,652599 \\
\hline Y6 & & & 0,47575 & X6 & 0,482511 & 0,73436 & 0,808507 & 0,942476 & 0,47575 & 0,645116 \\
\hline Y7 & & & 0,970033 & $\mathrm{X} 7$ & 0,904149 & 0,853938 & 0,831077 & 0,494428 & 0,970033 & 0,933977 \\
\hline Y8 & & & 0,964256 & X8 & 0,93996 & 0,853892 & 0,784883 & 0,485579 & 0,964256 & 0,913408 \\
\hline Y9 & & & 0,778938 & $\times 9$ & 0,785107 & 0,703365 & 0,533467 & 0,378145 & 0,778938 & 0,636301 \\
\hline
\end{tabular}

JURNAL SWABUMI Vol.9 No.2, September 2021: 117-126 


\begin{tabular}{|c|c|c|c|c|c|c|}
\hline $\mathrm{X} 10$ & 0,160513 & 0,115498 & 0,006929 & 0,076107 & 0,087938 & 0,077405 \\
\hline $\mathrm{X} 11$ & 0,201271 & 0,373935 & 0,277624 & 0,334863 & 0,275676 & 0,290134 \\
\hline $\mathrm{X12}$ & 0,482511 & 0,73436 & 0,808507 & 0,942476 & 0,47575 & 0,645116 \\
\hline $\mathrm{X} 13$ & 0,482511 & 0,73436 & 0,808507 & 0,942476 & 0,47575 & 0,645116 \\
\hline X14 & 0,904149 & 0,853938 & 0,831077 & 0,494428 & 0,970033 & 0,933977 \\
\hline X15 & $\overline{0}-149325$ & $\overline{0}, 089489$ & $\overline{0}, 178663$ & $\overline{-}, 063136$ & $-0,1184$ & $-\overline{0,093626}$ \\
\hline Y1 & 0,486792 & 0,499967 & 0,389645 & 0,406967 & 0,507806 & 0,465026 \\
\hline Y2 & 0,482511 & 0,73436 & 0,808507 & 0,942476 & 0,47575 & 0,645116 \\
\hline Y3 & $\overline{-}-371269$ & - & $\overline{-}, 349107$ & $\overline{0}-435442$ & $\overline{-}-370538$ & $\begin{array}{l}- \\
0,349144\end{array}$ \\
\hline Y4 & 0,482511 & 0,73436 & 0,808507 & 0,942476 & 0,47575 & 0,645116 \\
\hline Y5 & 0,904149 & 0,853938 & 0,831077 & 0,494428 & 0,970033 & 0,933977 \\
\hline Y6 & 0,482511 & 0,73436 & 0,808507 & 0,942476 & 0,47575 & 0,645116 \\
\hline Y7 & 0,904149 & 0,853938 & 0,831077 & 0,494428 & 0,970033 & 0,933977 \\
\hline Y8 & 0,93996 & 0,853892 & 0,784883 & 0,485579 & 0,964256 & 0,913408 \\
\hline Y9 & 0,785107 & 0,703365 & 0,533467 & 0,378145 & 0,778938 & 0,636301 \\
\hline Y10 & 0,482511 & 0,73436 & 0,808507 & 0,942476 & 0,47575 & 0,645116 \\
\hline Y11 & 0,904149 & 0,853938 & 0,831077 & 0,494428 & 0,970033 & 0,933977 \\
\hline Y12 & 0,482511 & 0,73436 & 0,808507 & 0,942476 & 0,47575 & 0,645116 \\
\hline Y13 & 0,904149 & 0,853938 & 0,831077 & 0,494428 & 0,970033 & 0,933977 \\
\hline Y14 & 0,93996 & 0,853892 & 0,784883 & 0,485579 & 0,964256 & 0,913408 \\
\hline Y15 & 0,243842 & 0,250569 & 0,18784 & 0,14653 & 0,25071 & 0,320119 \\
\hline
\end{tabular}

Berdasarkan pengujian Convergen validity dan Discrimanan Validity yang telah dilakukan didapatkan hasil perbandingan validitas sebagai berikut

Table 5 Perbandingan Validitas Convergen dan Diskriminan

\begin{tabular}{|c|c|c|c|}
\hline Variabel & Indikator & $\begin{array}{l}\text { Coverage } \\
\text { validity }\end{array}$ & $\begin{array}{l}\text { Discriminan } \\
\text { validity }\end{array}$ \\
\hline \multirow{5}{*}{$\begin{array}{c}\text { Kualita } \\
\text { informasi }\end{array}$} & $\mathrm{X} 1=$ ketepatan waktu & Valid & Valid \\
\hline & $\mathrm{X} 2=$ keringkasan & Valid & Valid \\
\hline & $\mathrm{X} 3=$ mudah difahami & Valid & Valid \\
\hline & X4= aktualitas & Valid & Valid \\
\hline & $\mathrm{X} 5=$ relevansi & Valid & Valid \\
\hline \multirow{7}{*}{ Kualitas sistem } & $\mathrm{X} 6=$ ketersediaan sistem & Valid & Valid \\
\hline & $\mathrm{X} 7=$ kecepatan respon & Valid & Valid \\
\hline & $\mathrm{X} 8=$ flexsibelitas & Valid & Valid \\
\hline & $\mathrm{X} 9=$ kemudahan pengguna & Valid & Valid \\
\hline & $\begin{array}{l}\mathrm{X} 10=\text { kelengkapan } \\
\text { berintegrasi }\end{array}$ & $\begin{array}{l}\text { Tidak } \\
\text { valid }\end{array}$ & Tidak valid \\
\hline & $\mathrm{X} 11=$ kendala sistem & $\begin{array}{l}\text { Tidak } \\
\text { valid }\end{array}$ & Tidak valid \\
\hline & $\mathrm{X} 12=$ konsistensi sistem & Valid & Valid \\
\hline \multirow{2}{*}{$\begin{array}{l}\text { Kualitas } \\
\text { pelayanan }\end{array}$} & X13=daya tanggap & Valid & Valid \\
\hline & $\mathrm{X} 14=$ jaminan & Valid & Valid \\
\hline
\end{tabular}

\begin{tabular}{|c|c|c|c|}
\hline & $\mathrm{X} 15=$ empati & $\begin{array}{l}\text { Tidak } \\
\text { valid }\end{array}$ & Tidak valid \\
\hline \multirow{4}{*}{ Pengguna } & $\mathrm{Y} 1=$ waktu menggunakan & $\begin{array}{l}\text { Tidak } \\
\text { valid }\end{array}$ & Tidak valid \\
\hline & $Y 2=$ frekwensi penggunaan & Valid & Valid \\
\hline & Y3= lama waktu koneksi & $\begin{array}{l}\text { Tidak } \\
\text { valid }\end{array}$ & Tidak valid \\
\hline & $\begin{array}{l}\text { Y4= pengulangan } \\
\text { penggunaan }\end{array}$ & Valid & Valid \\
\hline \multirow{4}{*}{$\begin{array}{l}\text { Kepuasan } \\
\text { pengguna }\end{array}$} & Y5=penilaian kepuasan & Valid & Valid \\
\hline & $\begin{array}{l}\text { Y6= kesulitan penggunaan } \\
\text { sistem }\end{array}$ & $\begin{array}{l}\text { Tidak } \\
\text { valid }\end{array}$ & Tidak valid \\
\hline & $\begin{array}{l}\text { Y7=kenyamanan } \\
\text { penggunaan sistem }\end{array}$ & Valid & Valid \\
\hline & $\begin{array}{l}\text { Y8= persyaratan kepuasan } \\
\text { penggunaan sistem }\end{array}$ & Valid & Valid \\
\hline \multirow{7}{*}{ Manfaat bersih } & $\begin{array}{l}\text { Y9= kesenangan terhadap } \\
\text { penggunaan sistem }\end{array}$ & Valid & Valid \\
\hline & $\begin{array}{l}\text { Y10 }=\text { menumbuhkan } \\
\text { kreatifitas }\end{array}$ & Valid & Valid \\
\hline & $\begin{array}{l}\text { Y11= peningkatan } \\
\text { pengetahuan }\end{array}$ & Valid & Valid \\
\hline & $\mathrm{Y} 12=$ manfaat & Valid & Valid \\
\hline & $\begin{array}{l}\text { Y13= kemampuan } \\
\text { memecahkan masalah }\end{array}$ & Valid & Valid \\
\hline & $\begin{array}{l}\text { Y14= meningkakan } \\
\text { partisipasi }\end{array}$ & Valid & Valid \\
\hline & $\begin{array}{l}Y 15=\text { tercapainya sharing } \\
\text { pengetahuan }\end{array}$ & $\begin{array}{l}\text { Tidak } \\
\text { valid }\end{array}$ & Tidak valid \\
\hline
\end{tabular}

Berdasarkan pertimbangan dari pengukuran tabel 6 maka indikator $X 10, X 11, X 15, Y 1, Y 3$, dan Y6. Setelah dilakukan proses droping langkah selanjutnya adalah menguji menguji kembali nilai AVE untuk membuktikan apakah semua variabel sudah valid atau belum. Untuk melanjutkan uji selanjutnya yaitu inner model syarat yang harus dilakukan adalah nilai AVE $>0,5$ (Sugiono \& abdillah, 2015). Dalam tabel AVE dibawah ini semua nilai AVE sudah $>0,5$ sebagai syarat untuk lanjut ketahap berikutnya sudah terpenuhi.

Table 6 Hasil Akhir Nilai AVE

\begin{tabular}{llll}
\hline & AVE & Akar AVE & Ket \\
\hline KI & 0,691566 & 0,691422 & Valid \\
\hline KS & 0,454971 & 0,612703 & Valid \\
\hline KP & 0,458765 & 0,676142 & Valid \\
\hline $\mathbf{P}$ & 0,532938 & 1 & Valid \\
\hline KPG & 0,72896 & 0,875489 & Valid \\
\hline MB & 0,585627 & 0,685634 & valid
\end{tabular}

3. Pengujian Composite Reliability

Composite reliability merupakan digunakan untuk mengukur nilai actual konsisten internal dan Cronbach alpha untuk mengukur batas bawah dari nilai konsisten, nilai dari kedua kontruk dinyatakan reliabel jika nilai Nilai Composite reliability dan Cronsback alpha di atas 0.07 (Mclean, 2016) 
Table 7 Composite Reliability dan Cronbach Alpha

\begin{tabular}{ccc}
\hline & $\begin{array}{c}\text { Composite } \\
\text { Reliability }\end{array}$ & Cronbachs Alpha \\
\hline KI & 0,917193 & 0,885556 \\
\hline KS & 0,887079 & 0,839585 \\
\hline KP & 0,806778 & 0,521074 \\
\hline $\mathbf{P}$ & 1 & 1 \\
\hline KPG & 0,965441 & 0,950597 \\
\hline MB & 0,914354 & 0,880599
\end{tabular}

Dilihat dari table 7 diperoleh nilai Composite reliability dan Cronsback alpha menun jukan nilai lebih dari 0.07 maka dinyatakan reliabel yang bagus.

4. Evaluasi Pengujian Model Struktural Iner Model

Model struktural dalam pls dievaluasi dengan menggunakan $\mathrm{R}^{2}$ untuk kontruk dependen, nilai koefisiensi path atau $t$-value tiap Path untuk uji signifikasi antar kontruk dalam model struktural. Nilai $R^{2}$ digunakan untuk mengukur tingkat variasi perubahan variabel independen terhadap variabel dependen. Semakin tinggi $\mathrm{R}^{2}$ berarti semakin baik model prediksi dari model penelitian yang diajukan.

Model struktural (inner model) merupakan pola hubungan variabel penelitian. Evaluasi terhadap model struktural adalah dengan melihat koefisien antar variabel dan nilai koefisien determinasi $\left(\mathrm{R}^{2}\right)$. Nilai $\mathrm{R}^{2}$ mensekati 1 , dengan kriteria batasan nilai dibagi menjadi 3 klasifikasi, yaitu 0,67= substansial, $0,33=$ moderat, dan $0,19=$ lemah (Chin, Diehl, \& norman, 1988)

Table 8 Nilai R-Square

\begin{tabular}{ll}
\hline & R Square \\
\hline KI & - \\
\hline KS & - \\
\hline KP & - \\
\hline $\mathbf{P}$ & 0,8568 \\
\hline KPG & 0,999999 \\
\hline MB & 0,98548 \\
\hline
\end{tabular}

Keterangan:
$\mathrm{KI}=$ kualitas informasi,

$\mathrm{KS}=$ kualitas sistem,

$\mathrm{KP}=$ kualitas pelayanan,

$\mathrm{P}=$ pengguna,

$\mathrm{KPG}=$ kepuasan pengguna,

$\mathrm{MB}=$ manfaat besih.

Berdasarkan gambar 8 diketahui bahwa kualitas pengguna, kepuasan pengguna dan manfaar besih mampu menjelaskan variabel kepuasan peengguna sekitas 0,999999 , variabel pengguna 0,8568 dan 0,98548 variabel manfaat bersih.

\section{A. Evaluasi goodness of fit (GoF)}

Formula $\mathrm{GoP}=\sqrt{\mathrm{COM} X R 2}$

Com=Rata-rata comunalitities

$\mathrm{R}^{2}=$ rata-rata nilai $\mathrm{R}$

Table 9 Nilai Akar Comunalitas R-Square

\begin{tabular}{lll}
\hline & Communality & R Square \\
\hline KI & 0,691422 & \\
\hline KS & 0,612703 & \\
\hline KP & 0,676142 & 0,8568 \\
\hline P & 1 & 0,999999 \\
\hline KPG & 0,875489 & 0,98548 \\
\hline MB & 0,685634 & 0,947426 \\
\hline Rata-Rata & 0,756898333 & \\
\hline
\end{tabular}

Maka GoP $=\sqrt{0,756898333 \times 0,947426}=$

\section{0,71710516}

Nilai GoP sebesar $\mathbf{0 , 7 1 7 1 0 5 1 6}$ dapat dikategorikan sebagai GoP besar, Sehingga dapat dinyatakan model telah sesuai secara substansial dalam mempresentasikan hasil penelitian (Hidayat \& Kurniawan, 2016).

\section{Pengujian hipotesis}

Setelah melakukan pengujian validitas konvergen, validitas diskriminan, dan reliabilitas, pengujian selanjutnya ialah menguji terhadap hipotesis, Nilai koefisien Path dan inner model menunjukan tingkat signifikan dalam pengujian hipotesis, ukuran signifikan keterdukungan hipotesis dapat digunakan perbandingan $\mathrm{T}$-tabel dan $\mathrm{T}$ - 
statistic,. Jika nilai nilai T-statistic lebih besar dari T-tabel maka hipotesis mendukung,didalam rule of thumbes PLS untuk tingkat keyakinan 95\% (Alpha 5 Persen), nilai T-tabel untuk hipotesis dua ekor (Two-tail) adalah lebih dari 1,96 dan untuk hipotesa satu ekor (one tailed) adalah lebih dari 1,64 hasil dari model strukturan (inner model) dalam penelitian ini dapat dilihat pada table 10 Berikut:

Table 10 Tabel T-Statistic

\begin{tabular}{|c|c|c|c|c|c|}
\hline & $\begin{array}{c}\text { Original } \\
\text { Sample (0) }\end{array}$ & $\begin{array}{l}\text { Sample } \\
\text { Mean (M) }\end{array}$ & $\begin{array}{l}\text { Standard } \\
\text { Deviation } \\
\text { (STDEV) }\end{array}$ & $\begin{array}{l}\text { Standard } \\
\text { Error } \\
\text { (STERR) }\end{array}$ & $\begin{array}{c}\mathbf{T} \\
\text { Statistics } \\
(\mid \mathbf{O} / \mathrm{STER} \\
\mathbf{R} \mid)\end{array}$ \\
\hline $\begin{array}{c}\mathrm{KI}-> \\
\mathbf{P}\end{array}$ & $-1,027464$ & $-1,020201$ & 0,190044 & 0,190044 & 5,40646 \\
\hline $\begin{array}{l}\mathrm{KI}-> \\
\mathrm{KPG}\end{array}$ & 0,841223 & 0,851247 & 0,183483 & 0,183483 & 4,58474 \\
\hline $\begin{array}{l}\text { KS - } \\
>P P\end{array}$ & 0,834928 & 0,912298 & 0,680753 & 0,680753 & 1,226477 \\
\hline $\begin{array}{c}\mathrm{KS}- \\
\mathrm{KPG}\end{array}$ & 0,336083 & 0,265934 & 0,556059 & 0,556059 & 0,604402 \\
\hline $\begin{array}{l}K P- \\
>P\end{array}$ & 0,877064 & 0,812167 & 0,552395 & 0,552395 & 1,587749 \\
\hline $\begin{array}{c}\mathrm{KP}- \\
\mathrm{KPG}\end{array}$ & $-0,238942$ & $-0,166549$ & 0,439989 & 0,439989 & 0,543065 \\
\hline $\begin{array}{l}P-> \\
K P G\end{array}$ & $-0,817758$ & $-0,83084$ & 0,072159 & 0,072159 & 11,33274 \\
\hline $\begin{array}{l}P \rightarrow> \\
M B\end{array}$ & $-0,220756$ & $-0,209125$ & 0,05707 & 0,05707 & 3,868201 \\
\hline $\begin{array}{l}\text { KPG } \\
-> \\
M B\end{array}$ & 0,774879 & 0,754893 & 0,06303 & 0,06303 & $\begin{array}{c}12,29374 \\
6\end{array}$ \\
\hline
\end{tabular}

Dalam pengujian hipotesis untuk model regresi, derajat bebas atau df (degree of freedom) ditentukan dengan rumus $\mathrm{n}-$ $k$, dimana $n=$ banyak observasi sedangkan $\mathrm{k}$ banyak variabel (bebas terkait)

$$
\begin{aligned}
& D f=\mathrm{n}-\mathrm{k} \\
& \quad=45-6=39 \\
& D f=39 \text { dan } a=5 \% \text { maka T-tabel }=
\end{aligned}
$$

1,68 .

Pengujian hipotesis 1 pada model struktural menyatakan bahwa kualitas Informasi berpengaruh signifikan terhadap pengguna, berdasarkan $T$-statistic kontruk adalah sebesar 5,40646 >1,68, menunjukan bahwa kualitas informasi berpengaruh signifikan terhadap penggunaan maka dapat dinyatakan bahwa:

Hipotesis 1 didukung.

Pengujian hipotesis 2 pada model struktural menyatakan bahwa kualitas Informasi berpengaruh signifikan terhadap kepuasan pengguna, berdasarkan $T$-statistic kontruk adalah sebesar $4,58474>1,68$, menunjukan bahwa kualitas informasi berpengaruh signifikan terhadap kepuasan penggunaan maka dapat dinyatakan bahwa Hipotesis 2 didukung.

Pengujian hipotesis 3 pada model struktural menyatakan bahwa kualitas Sistem berpengaruh signifikan terhadap pengguna, berdasarkan T-statistic kontruk adalah sebesar $1,226477<1,68$, menunjukan bahwa kualitas sistem tidak berpengaruh signifikan terhadap penggunaan maka dapat dinyatakan bahwa Hipotesis $\mathbf{3}$ tidak didukung.

Pengujian hipotesis 4 pada model struktural menyatakan bahwa kualitas Sistem berpengaruh signifikan terhadap kepuasan pengguna, berdasarkan T-statistic kontruk adalah sebesar $0,604402<1,68$, menunjukan bahwa kualitas sistem tidak berpengaruh signifikan terhadap kepuasan penggunaan maka dapat dinyatakan bahwa Hipotesis 4 tidak didukung.

Pengujian hipotesis 5 pada model struktural menyatakan bahwa kualitas pelayanan berpengaruh signifikan terhadap pengguna, berdasarkan T-statistic kontruk adalah sebesar $1,587749<1,68$, menunjukan bahwa kualitas pelayanan tidak berpengaruh signifikan terhadap penggunaan maka dapat dinyatakan bahwa Hipotesis 5 tidak didukung.

Pengujian hipotesis 6 pada model struktural menyatakan bahwa kualitas pelayanan berpengaruh signifikan terhadap kepuasan pengguna, berdasarkan T-statistic kontruk adalah sebesar 0,543065 $<1,68$, menunjukan bahwa kualitas pelayanan tidak berpengaruh signifikan terhadap kepuasan penggunaan maka dapat dinyatakan bahwa Hipotesis 6 tidak didukung.

Pengujian hipotesis 7 pada model struktural menyatakan bahwa pengguna berpengaruh signifikan terhadap kepuasan pengguna, berdasarkan T-statistic kontruk adalah sebesar $11,33274>1,68$, menunjukan bahwa pengguna berpengaruh signifikan terhadap kepuasan penggunaan maka dapat dinyatakan bahwa Hipotesis 7 didukung. 
Pengujian hipotesis 8 pada model struktural menyatakan bahwa pengguna berpengaruh signifikan terhadap manfaat bersih, berdasarkan T-statistic kontruk adalah sebesar 3,868201 >1,68, menunjukan bahwa pengguna berpengaruh signifikan terhadap manfaat bersih maka dapat dinyatakan bahwa Hipotesis 8 didukung.

Pengujian hipotesis 8 pada model struktural menyatakan bahwa kepuasan pengguna berpengaruh signifikan terhadap manfaat bersih, berdasarkan T-statistic kontruk adalah sebesar 12,293746 $>1,68$, menunjukan bahwa kepuasan pengguna berpengaruh signifikan terhadap manfaat bersih maka dapat dinyatakan bahwa Hipotesis 9 didukung.

\section{Kesimpulan}

Berdasarkan hasil evaluasi dari penelitian diperoleh hasil maka terbentuklah model akhir dari penelitian ini kemudian dilakukan uji signifikan lagi untuk membuktikan bahwa semua variabel sudah signifikan sesuai dengan lima hipotesis yang diterima yang tersaji pada gambar dibawah ini.

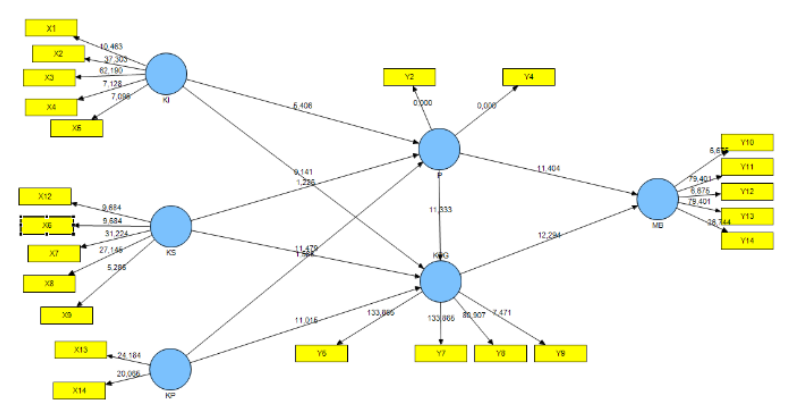

Gambar 4 Model Akhir Penelitian

Kesimpulan dari Penelitian menunjukan bahwa: Kualitas Informasi (KI) berpengaruh signifikan terhadap Pengguna $(\mathrm{P}), \mathrm{H} 1$ diterima, Kualitas Informasi (KI) berpengaruh signifikan terhadap Kepuasan Pengguna (KPG) H2 diterima, Kualitas Sistem (KS)berpengaruh signifikan terhadap Pengguna (P) H3 ditolak, Kualitas Sistem (KS)berpengaruh signifikan terhadap Kepuasan Pengguna (KPG) H4 ditolak, Kualitas Pelayanan (KP) berpengaruh signifikan terhadap Pengguna (P) H5 ditolak, Kualitas Pelayanan (KP)berpengaruh signifikan terhadap Kepuasan Pengguna (KPG) H6 ditolak, Pengguna (P)berpengaruh signifikan terhadap kepuasan Pengguna (KPG) H7 diterima, Pengguna (P)berpengaruh signifikan terhadap Manfaat Bersih (MB) H8 diterima,Kepuasan Pengguna (KPG) berpengaruh signifikan terhadap Manfaat Bersih (MB) H9 diterima.

\section{Referensi}

Agustina, H., \& Kriwangko, P. (2017). Pengaruh Gaya Kepemimpinan Transformasional dan Transaksional terhadap Organizational Citizenship Behavior di Sushi Tei Galaxy Mall Surabaya The Impact of Transformational and Transactional Leadership Style on Organizational Citizenship Behavior in Sushi. 5, 96109.

Asnawi, N. (2018). Pengukuran Usability Aplikasi Google Classroom Sebagai Elearning Menggunakan USE Questionnaire (Studi Kasus: Prodi Sistem Informasi UNIPMA). RESEARCH: Computer, Information System \& Technology Management, 1(1), 17. https://doi.org/10.25273/research.v1i1.2 451

Astalini, A., Maison, M., Ikhlas, M., \& Kurniawan, D. A. (2018). the Development of Students Attitude Instrument Towards Mathematics Physics Class. Edusains, 10(1), 46-52. https://doi.org/10.15408/es.v10i1.7213

Farabi, N. A. (2016). Analisis Penerapan Sistem informasi ZISW Dengan Menggunakan Metode UTAUT. Indonesian Journal on Computer and Information Technology, 1(2), 71-79.

Harefa, N., \& Sumiyati, S. (2020). Persepsi Siswa terhadap Google Classroom sebagai LMS pada masa Pandemi Covid-19. Science Education and Application Journal, 2(2), 88. https://doi.org/10.30736/seaj.v2i2.270

Hidayat, A., \& Kurniawan, C. (2016). Pengaruh Konsep Diri Dan Kepercayaan Diri Terhadap Perilaku Konsumtif Pembelian Gadget Pada Mahasiswa Fakultas Hukum Non. AnNafs, 10(01), 1-10.

Hidayatullah, S., Khouroh, U., Windhyastiti, I., Patalo, R. G., \& Waris, A. (2020). Implementasi Model Kesuksesan Sistem Informasi DeLone And McLean Terhadap Sistem Pembelajaran 
Berbasis Aplikasi Zoom Di Saat Pandemi Covid-19. Jurnal Teknologi Dan Manajemen Informatika, 6(1), 4452. https://doi.org/10.26905/jtmi.v6i1.4165

Kualitas, A., Kerja, K., Kerja, D. A. N. K., Cv, P., Senenan, D., \& Arifin, N. (2012). Analisis Kualitas Kehidupan Kerja, Kinerja, Dan Kepuasan Kerja Pada Cv Duta Senenan Jepara. Jurnal Economia, 8(1), 11-21. https://doi.org/10.21831/economia.v8i1. 797

Kurniati, E., Nur Alfaeni, D. K., \& Andriani, F. (2020). Analisis Peran Orang Tua dalam Mendampingi Anak di Masa Pandemi Covid-19. Jurnal Obsesi : Jurnal Pendidikan Anak Usia Dini, 5(1), 241.

https://doi.org/10.31004/obsesi.v5i1.541

Maulana, H. A. (2021). Persepsi Mahasiswa terhadap Pembelajaran Daring di Pendidikan Tinggi Vokasi: Studi Perbandingan antara Penggunaan Google Classroom dan Zoom Meeting. Edukatif: Jurnal IImu Pendidikan, 3(1), 188-195.

https://doi.org/10.31004/edukatif.v3i1.25 9

Mclean, D. D. A. N. (2016). Jurnal Sistem Informasi ( Journal of Information Systems ). 1 / 12 ( 2016 ), 1-8 DOI: http://dx.doi.org/10.21609/jsi.v12i1.444. $12,1-8$.

Nariswari, R., \& Iriawan, N. (2012). Analisis Pengaruh Kualitas Layanan, Kepuasan Surabaya dengan Pendekatan SEM Bayesian. Jurnal Sains Dan Seni ITS, 1(1), 248-252.

Nurfalah, E. (2019). Optimalisasi E-Learning berbasis Virtual Class dengan Google Classroom sebagai Media Pembelajaran Fisika. Physics Education Research Journal, 1(1), 46. https://doi.org/10.21580/perj.2019.1.1.3 977

Prayudi, D., \& Oktapiani, R. (2020). Pengukuran Kualitas Sistem Informasi Pendaftaran Pasien Dengan Model
DeLone McLean (Studi Kasus pada Aplikasi Mobile RS Hermina). Jurnal IImiah IImu Ekonomi, 9(1), 22-28. https://jurnal.ummi.ac.id/index.php/JIIE/ article/view/731/382

Rifai, A. (2015). Partial Least SquareStructural Equation Modeling (PLSSEM) untuk mengukur ekspektasi penggunaan repositori lembaga: Pilot studi di UIN Syarif Hidayatullah Jakarta. Al-Maktabah, 14(1), 56-65.

Suri, M. (2020). Journal of Education Science ( JES ), 6 ( 2 ), Oktober 2020 APLIKASI GOOGLE CLASSROOM DALAM PEMBELAJARAN MATA KULIAH BAHASA INGGRIS DI MASA PANDEMI COVID-19 THE APPLICATION OF GOOGLE CLASSROOM IN THE ENGLISH LANGUAGE TEACHING LEARNING DURING PANDEMIC COVI. 6(2).

Suriadi, H. J., Firman, F., \& Ahmad, R. (2021). Analisis Problema Pembelajaran Daring Terhadap Pendidikan Karakter Peserta Didik. Edukatif: Jurnal IImu Pendidikan, 3(1), 165-173.

https://doi.org/10.31004/edukatif.v3i1.25 1

Vogt, W. (2015). Structural Equation. In Dictionary of Statistics \& Methodology. https://doi.org/10.4135/9781412983907. n1909

Wiguna, R., Sutisnawati, A., \& Lyesmaya, D. (2020). Jurnal perseda. Jurnal Persada, III(2), 75-79.

Wulandari, I. A. G. (2021). Pemanfaatan Media Google Classroom Dalam Meningkatkan Mutu Pembelajaran Pada Masa Pandemi Covid-19 Di Ihdn Denpasar. Jurnal Penjaminan Mutu, $7(1), 45-52$.

Yuliana, K., \& Afriani, D. (2020). Analisis Sistem Penerimaan Peserta Didik Baru ( PPDB ) Online SMP Negeri di Kota Banjarmasin dengan Menggunakan Model Kesuksesan Sistem Informasi Delone dan Mclean. Jurnal Infokam, $X V I(1), 1-12$. 